Journal of Educational Research in Developing Areas (JEREDA)

Vol. 2. Issue 1, Pp. 76-85, 2021

http://www.jeredajournal.com

E-mail: info@jeredajournal.com

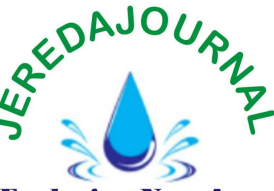

Exploring New Areas

Mini Review DOI: https://doi.org/10.47434/JEREDA.

eISSN: $2735-9107$

\title{
DISABILITY ACT OF 2019: A RIPOSTE FOR INCLUSION OF PERSONS WITH SPECIAL NEEDS IN NIGERIA
}

\section{${ }^{1}$ Hammed Gbenga Adewale, ${ }^{2}$ Elizabeth Folasade Oluyomi, ${ }^{* 3}$ Rufus Olanrewaju Adebisi}

\author{
${ }^{1}$ Postgraduate school, Department of Special Education, University of Ibàdan. Nigeria \\ ${ }^{2}$ Federal College of Education, Okene, Nigeria \\ ${ }^{3}$ Federal College of Education (Special), Oyo, Nigeria \\ 19gbengusy@gmail.com, ${ }^{2}$ folasadeelizabeth48@gmail.com; ${ }^{3}$ aderufus2@gmail.com \\ *Corresponding author: ${ }^{1}$ aderufus2@gmail.com \\ (1) https://orcid.org/0000-0003-1108-7431
}

Received: $20^{\text {th }}$ February, 2021; Revised: $20^{\text {th }}$ March, 2021; Accepted: $8^{\text {th }}$ May, 2021

\begin{abstract}
Introduction: The unfriendly relationship between society and individuals with special needs have been debated several times. The term "inclusion" resurfaces at the end of symposium and meetings as resolution to that by the conveners with a belief that such might end the negative attitudes towards individuals with special needs within the society.

Purpose: This review was to add to the non available literature for the use of researchers, students, policy makers and lovers of persons with special needs who would like to seek for literature to discuss the new disability act in Nigeria

Findings: The paper reviewed the intangible sense of inclusion and discussed the roles of the new disability act would play towards making the participation, engagement and involvement of individuals with special needs in the development of the nation for nation building.

Recommendations: The paper recommended among others; considerable monetary allocation and disbursement for its execution; urgent, massive recruitment of the required personnel; collaboration and partnership between administrators and the authorities in the field of special needs education to be set up, and that government should embark on considerable infrastructures and equipping of schools, hospitals, and economic institutions.
\end{abstract}

Keywords: Disability Act, Inclusion, Persons with Disabilities, Discrimination, Persons with Special Needs.

Crossref Adewale, H. G., Oluyomi, E. F., \& Adebisi, R. O. (2021). Disability act of Cited-by 2019: A riposte for inclusion of persons with special needs in Nigeria. Journal of Educational Research in Developing Areas, 2 (1), 76-85. https://doi.org/10.47434/JEREDA.2.1.2021.76.

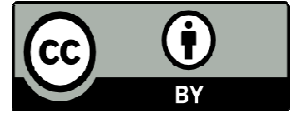

Copyright (c) 2021 The author(s) of this article retain(s) the copyright. 


\section{PUBLIC INTEREST STATEMENT}

There is no doubt that persons with special needs are often excluded directly or indirectly from development processes due to chain of obstacles such as physical, communication, institutional, attitudinal, co-opted barriers, lack of participation, inadequate data or statistics, evidence on what works and inaccurate concerns spontaneously have given away or jettisoned likelihoods of enticing gainful employment. This review will be of interest to researchers, policy makers and lovers of persons with special needs who would like to seek for literature to discuss the new disability act in Nigeria.

\section{INTRODUCTION}

Will this suffering ever end, what could have happen to deserve mistreatment from fellow being, is this how one will continue to live and for how long are we going to endure and feel rejected in our collectively owned homeland?

These and quite a few others apprehension and uncertainties have been raised ever before now by persons with special needs including experts in the field of special education and rehabilitation sciences with the mandate to saddle the wellbeing of persons with special needs then and here known as exceptional children, which might be due to the way and manner such individuals are in disguise in Nigeria. The scuffle seems to have been as a result of who, where, what, when, and how as far as the issue of persons with special needs is concerned. In the sense that, not everyone appears to know who persons with special needs are and not particularly the genesis of their problems as well as the strengths and weaknesses possessed by such individuals might still not be well known to the general public, not to talk of having the clear picture of the individuality and peculiarity of these personalities in question. If at all there is an urge for persons to take the blame for the exclusivity of their circumstances, that should not have been the persons with special needs either nature and human trait (called gene) should be questioned. However, that might not be needed as intelligent people will never devote their valuable time to meditate over a problem, but at all cost certify, the problem is well tackled within the shortest available time. This seems not to have been the case of Nigeria as a matter of fact that too much of necessary time has been wasted while analyzing the dynamics of individual difference in its diverse cultures rather than getting away to safeguard and lifelike the better future of these persons in Nigeria.

This oversight might have left persons with special needs and their relatives facing drawback when trying to align themselves with the happenings and diminuendos of the society; before and after the ratification of safety and inclusion of persons with special needs by the United Nations. Even though the ratification of the disabled rights requires a backup either from the law-making body or law operating by each member state of the United Nations. This has been dramatically witnessed in advanced countries and even among those who are sister countries to Nigeria. Meanwhile, in Nigeria, the persons with special needs were left in a state of oblivion as regards the equality of opportunity and demolition of idiosyncrasy discernment being conceived about persons with special needs; of which if the case is not taken might be a blocking stone for the trailblazing and advancement of persons with special needs in all capacities of life.

After the long-awaited positive response from the Nigerian government, the anticipated bill was concluded to see the light when no one predicted it (principally on the verge of election) due to the fact that most advocates of the bill are getting wind-down of their efforts towards ensuring the fundamental rights of persons with special needs become prioritized and tenable through the docketed "disability bill," that was exasperated by nothing but a pointless 
halt on the part of bureaucrats, who might not have considered such bill as necessary as that of oil and gas. Now that the Nigerian government has decided not to just passed the bill into law but consented to it as abiding force on all and sundry for the protection of persons with special needs. Hitherto, probes that may have been bred by the newly disability act could be its worth mentioning, its inspiration for persons with special needs as well as its allusion on the part of the society forcing a leitmotif that "disability act of 2019 is a riposte for the inclusion of persons with special needs". Through which many including scholars, believe to have opened up all spheres of influence for persons with special needs on $a$ genuinely equal basis.

\section{INCLUSION AS ITS STAND}

To say disability and devaluation are linked is not an irony. This is because an individual with special needs who lack access to education and skills development opportunity spontaneously have given away or jettisoned likelihoods of enticing gainful employment (Braithwaite \& Mont, 2007); which in turn has led to a decrease in per capita income of persons with special needs, inability to meet regular prerequisites and footing the extra expenditures escalated from regular health care, rehabilitation, assistive devices to exorbitant transportation preferences (DFID, 2000; 2002) that contributed the majority of persons with special needs into economic hardship (Braithwaite and Mont, 2007). Whereas, societies breathing abject poverty are at risk of acquiring disabilities (Barron \& Ncube, 2010) owing to the inability to afford the use of health care services, clean water and non-threatening environments that may be occasioned to individuals having health issues and impairments (United Nations Department of Economic and Social Affairs, 2011; Smith, Jolle \& Schmidt, 2012). Without any iota of doubt, the reckoning of disabilities with inability could have served as a deterrent to a group (particularly those with special needs) to fully and effectively play a part in their nation-building on an equal basis with others. That is to say, the exclusion is not only real but exits as well within social cultures. There is no doubt that persons with special needs are often excluded directly or indirectly from development processes in addition to public-spirited enterprise due to chain of obstacles such as physical, communication, institutional, and attitudinal, co-opted barriers, lack of participation, inadequate data or statistics, evidence on what works and inaccurate concerns (Rohwerder, 2015). Apparently, the invisibility of persons with special needs coupled with lack of recognition as a distinct group with irreplaceable consternations, inadequate proof of identity as well as the nonappearance of reasonable accommodation cannot be undermined as factors for the exclusion of the majority of persons with special needs from health, legal, psychosocial, safe livelihood opportunities, and other services are evident. The enormousness end product of their segregation and elimination particularly from government and development agenda and services seem to have steered an increased inequality, discrimination and downgrading reported to be roughcasting persons with special needs (Heymann, Stein, \& Moreno, 2014; Groce \& Kett, 2014; Bruijn, Regier, Cornielje, Wolting, van Veen, \& Maharaj, 2012; World Health Organisation and World Bank, 2011) in Nigeria. As a result, dislodging such outlook, perspicacity, and attitude from every nook and cranny of the Nigerian social sphere, setting a standard practice and vivacity in terms of inclusive milieu turn out to be requisite. As postulated by Chartered Institute of Personnel and Development (2019), the word inclusion is far and wide held term, but a rickety one that is being used across disciplines. In line with that, Arbetsgivarverket (2008) described inclusion as:

"A change in structure and system so that they, without obstacles along the way, support the possibility to utilize the relevant competence that people have. 
Inclusion is not a strategy to make people fit into existing systems and structures. Inclusion is not equivalent to integration".

To Hodkinson (2011), inclusion is an agent of accountability and standards. The term "inclusion" means appreciating and valuing human divergences through an atmosphere that promotes a sense of belonging where one and all feel respected and respected for their distinctiveness (CBM, 2012). As far as this write-up is concerned, inclusion is an all encompasses engagement that deals with the incorporation of a person or group of persons with special needs to the display place of growth routes and make it quickly reached irrespective of susceptibility being accrued by such individuals (Al Ju'beh, 2015; Mitra, 2013). In this context, inclusion is nothing but a setting up enthralling society to give equal access to education, health care services, labour and service, and social protection among its members including persons with special needs (United Nations Department of Economic and Social Affairs, 2011; Morgon \& Polack, 2014). Moreover, inclusion is a process of leaving no one behind instead ensure there are opportunities for all in the area of economic, political and social institutions by tackling the structural barriers that restrain people from opportunity and tracking progress across different population groups (Wissenbach, 2014; Barron \& Amerena, 2007). The realization of inclusion tends to aid the reduction of poverty and to achieve developmental outcomes across all economic and social population groups, particularly among persons with special needs (World Health Organisation and World Bank; Carter, 2015). In the same way, inclusion on the part of the individual with special needs does not only prompt enablement for this group of individuals, but it is an itinerary to move such individuals from being considered "vulnerable" to become resource and donors of progression in their respective society (Rohwerder, 2015; DESA, 2011; Walton, 2012).
Nevertheless, rising support for inclusion by reputable institutions and individuals might not only be fruitful to persons with special needs and their families instead to the wide-ranging public as tryst of the so-called disregarded persons to an exquisite and ordinary facet of life is feasible to reinforce a hale and hearty relationship concerning the individuals and their host habitation (International Disability and Development Consortium (IDDC), 2012; Bruijn, Regier, Cornielje, Wolting, van Veen \& Maharaj, 2012). Alike, the inclusion of persons with special needs undeviating for their physical presence in societal events and then again make a fuss of the impact of civil commitment of such beings in a resolution of affected matters are not planned or implemented without their input (Chartered Institute of Personnel and Development, 2019) in conformity with Yoruba saying that "a kin farileyinolori (whithout them, nothing should be done)." With the attitudinal change of "inclusiveness," all members of the society, most especially persons with special needs, feel safe, respected, and comfy for being themselves and able to express all aspects of their individualities (Coe \& Wapling, 2010; Coe, 2012). On the other hand, Corporation for National and Community Service (2004) asserted that inclusion is a norm in which each person (with or without special needs) permit to shares a sense of belonging with others in the same society devoid of any form of discrimination. Inclusion is a continuous process that evolves and responds to vicissitudes in the environs or in policies (Women Refugee Commission, 2015). This practice of aligning available prospects in the society (known as inclusion) tend to be advantageous to the personalities identified with special needs and their counterparts without any distinctiveness (United Nations Development Programme, 2010) from the enhancement of abilities, vision, and selfworth to take part in society (United Nations, 2013) to the making of healthy life and wellbeing through a supportive community for persons with special needs (Ferrie, 2008). 
In an inclusive setting, persons with special needs are not only recognized and developed but valued as part of the range of diversity that exists in the anthropoid state with their skills routinely utilized for full participation in politics, social and monetary activities of their nation (United Nations, 2013; World Bank, 2013; Nordic Consulting Group, 2012; United Nations Department of Economic and Social Affairs, 2011; Cappo, 2002). Thus, persons with special needs are not only having the right to the mode of education of their choice or right for their political participation but can actually take part in the process, using their right to education and that of voting strength to actually get their decision counts in a political process. That is, the most significant reason for creating an inclusive society is for the general public, including persons with special needs to get involved in the process by which their society is managed, ordered, and represented without snubbing self-dignity of humans.

\section{DISABILITY ACT: A BRIDGE TO INCLUSION}

Globally, it has been longestablished that persons with special needs are more likely to experience health inequalities, primary health conditions, or dies younger than other people (Equality and Human Rights Commission, 2017; Adams \& Oldfield, 2012). While the majority of persons with special needs are living in poverty or are materially deprived as compared to the abled, this is because their educational attainment is nearly three times lower than the abled, and just a few of such individuals are taking-up for apprenticeships (Clarke, 2016; Equality and Human Rights Commission, 2014; EHRC, 2013). Aside from that, matters like poor access to transportation, leisure, and other services are undeniable barriers against independent life, acceptable standard of living, and satisfactory day-to-day activities of persons with special needs (Joseph Rowntree Foundation, 2016). Meanwhile, in Nigeria, over twenty (20) million people (approximately $10 \%$ of the country's population) are being projected as persons with special needs who are not just living with one form of disability or the other but facing negative societal attitude and stigmatization from their various communities. Thus, it is a wise decision to put an end through a pooled of effort between the general public and that of people at the wheel of governance; to all mythical verdict, the society has placed on persons with special needs including barriers impeding the chance to play their part in nationbuilding fully.

Subsequently, the Nigerian government under the control of Commander-in-Chief of Armed forces, President Muhammadu Buhari, conceded to the people's call for Disability Act. This act was signed into law in 2019 that is nineteen years after it was proposed as the discrimination against persons with disabilities (prohibition) bill. The willpower and never give in the spirit of various organizations of persons with special needs, connoisseurs in Special Education, law practitioners, charitable/non-governmental

organizations, and host of other interest groups is creditable for the realization of this act. In fact, its enactment seems to be a giant stride so far taken by the Nigerian government as a process of inclusion for persons with special needs. Its provisions include the prohibition of discrimination and awareness programmes for persons with special needs; free health care service with particular communication at the hospital; provision of the appropriate mode of education for persons with special needs and inclusive education, making physical structures such as public building and premises accessible for persons with special needs with the erection of sidewalk and specialized facilities and reserved spaces for persons with special needs; making transportation services and facilities accessible for persons with special needs within five years of its enactment.

Also, as part of the provision of the disability act of 2019 is the reserved necessities for individuals with special to be first considered when they are on 
queues, or as related to the issue of accommodations and emergencies. Regrettably, ever since the reception of the so-called "Disability Act" in Nigeria, persons with special needs are still not being treated as equal citizens and continue to be evicted off the everyday rights, their abled counterparts take for granted, such as being able to access transport, grocery shops or shopping centres, public buildings and its premises, befitting health services and housing, and as well benefit from inclusive education and employment. The disability pay gap is still tenacious and broadening.

It is crucial for the public to be conversant with the "Disability Act" and urgently and systematically addressed the structural problems so that persons with special needs will no longer be treated as 'second class citizens or further lay open to incarceration in their homeland. Even though the plan and decision of the government as far as inclusion is concerned are well captured and reflected by the disability act of 2019, but the main issue is moving away from principle to action. For instance, twelve months after the public pronouncement of this "Act," the needed means for its success is still not being arrayed. This situation is a reminder of the position of Howlett, Ramesh \& Perl (2009) that the effectiveness of a policy lies in the funds allotted, personnel assigned for it, as well as its rules of procedure which are strong-willed that must not be faulted or else its effective execution becomes far from reach. In consequence, the needed personnel is yet to be deployed by the National Commission for persons with disabilities, even though the commission with such mandate has since been inaugurated. There are indications that Nigeria government still have a lot to do as pintsized or zilch was budgeted in the appropriation bill of the year 2021 for this initiative. More so, the proposition of five years moratorium could delusion the tackling of structural exclusion in such areas as employment, education, transport, social amenities, public services, and communications. In other words, ensuring persons with special needs to take up socially responsible and productive roles in civil society seems to have been putting on hold as directly requested persons with special needs to withstand their ordeal pending the time appropriate measure will be taken.

\section{CONCLUSION}

The Year 2019 remains an unforgettable year in the history of Nigeria; as a matter of fact, it is a year the country begins a journey towards equity and respect for the multiplicity of human nature. The year launch a remarkable piece of a fundamental right for persons with special needs. Even though a good policy does not often translate to a well-heeled agenda. This is because one thing is to initiate and set a policy blueprint or plan; another thing is the execution. The passing of this bill is an important step; changes in both the physical and social structure of the country has to occur before its aims can be actualized. That is, we need to eliminate discrimination, advance equality of opportunity, and make Nigeria an inclusive and supportive society for persons with special needs. Notionally, inclusion does not adjust the needs of persons with special needs to the prevailing social standards; instead, society has to adjust its social norms to meet the needs of persons with special needs. With the enactment of disability act of 2019, inclusion is no longer a matter of moral obligation but as a legal and developmental obligation expressly, for persons with special needs to realize their rights to take control of their own lives, make their own choices, to develop their potential and have their needs fulfilled through the capability to access public services, transport, schools, and leisure activities. The Disability Act bent to aid persons with special needs to have a formidable relationship and live an independent life through the evacuation of stigma. However, It is important for all Nigerians to take practical steps to support the implementation of disability act which as of today remains the only mechanism to help the country becomes an egalitarian society. 


\section{RECOMMENDATIONS}

In reality, time and tide wait for nobody, which is the reason for the immense outlay of the following in less than five awaiting years of full implementation of the disability act:

1. Considerable monetary allocation and disbursement for its execution

2. Urgent, massive recruitment of the required personnel (particularly the certified in special needs education should be done as soon as possible.

3. Collaboration and partnership between administrators and the authorities in the field of special needs education should be set up.

4. The government should embark on considerable infrastructures and equipping schools, hospitals, and economic institutions.

5. Rapid rehabilitation of the existing public buildings and structures should come.

6. Contact should be made with the officials at the Ministry of Health on issues regarding the implementation of the section on health provisions.

Conflicts of Interest: The authors declare no conflict of interest.

Disclaimer Statement: We hereby declare that this paper is our autonomous work. All texts either quoted directly or paraphrased have been indicated by intext citations. Full bibliographic details are given in the reference list. This work has not been submitted to any other examination authority.

\section{Notes on Authors:}

Hammed G. Adewale is a PhD student in the Department of Special Education, University of Ibadan, where he obtained a Masters degree in the field of Learning Disabilities. The scholastic records ascribe to his broad level of academic prowess and outstanding had received meritorious awards from the governing councils of the various institutions he has attended without an oversight by the School Senate of University of Jos and that of Federal College of Education (SP)
Oyo where he had his Bachelor Degree and National Certificate on Education in Special Needs Education and Rehabilitation Science/Computer Science Education respectively. His research interests include inclusiveness, assistive technology for children with special needs, reading performance of individuals with learning disabilities. Currently working on psychosocial and attitudinal change via photomagazine and motion pictures, and Non-pharmacological cognitive Based techniques for Mental Emotional and Behavioural problems of Adolescents.

Elizabeth Folasade Oluyomi is a certified educationist and a teacher. She is presently a lecturer with the Department of Special Education, Federal College of Education, Okene, Kogi State, Nigeria. She is a member of many professional associations. Her research interests are in Learning Disabilities, Reading. She has attended conferences and published several articles in National and International Journals. Her hobbies are: reading and making friends.

Rufus Olanrewaju Adebisi is a graduate of Federal College of Education (Special) Oyo and Department of Special Education and Rehabilitation Sciences, University of Jos, Jos, Plateau State, Nigeria, where he bagged Nigeria Certificate in Education (NCE) and Bachelor in Education (BEd), Master in Education (MEd), Doctor of Philosophy $(\mathrm{PhD})$ in Special Education respectively. $\mathrm{He}$ is currently teaching at his AlmaMata, in the Department of Education for Learners with Communication and Behaviour Disorders, Federal College of Education (Special) Oyo, Oyo State, Nigeria. His research interests are in Learning Disabilities, Autism Spectrum Disorders, Attention Deficit Hyperactivity Disorders and trace elements/micronutrients in managing disabilities. He is a researcher, manuscript Reviewer, Editor and Managing Editor, currently serving as member of Editorial Boards in many national and international Journals. He has attended conferences and published 
several articles in National and International Journals.

Authorship and Level of Contribution: The first author searched the literature, wrote and compiled the manuscript, while the second and third authors brought the materials consulted together, reviewed it. Moreover, all the authors participated in the review of the paper.

\section{REFERENCES}

Adams, L., \& Oldfield, K. (2012). Opening up: The views of disabled people and people with long-term health conditions. EHRC. Research Report 77.

AlJu'beh, K. (2015). Disability inclusive dev elopment toolkit. Bensheim: CBM. htt p://www.cbm.org/article/downloads/ 54741/CBM-DID-TOOLKITaccessible.pdf

Arbetsgivarverket. (2008). An inclusive approach: A strategy for diversity in the central Government Sector. Challenges, Policy strategy for government employers 2007- 2010 ( Swedish Agency for Government Emp loyers). Stockholm. www.arbetsgivar verket.se.

Barron, T., \& Amerena, P. (Eds.).(2007). Disability and inclusive development. Leonard Cheshire Disability.

Barron, T., \& Ncube, J. M. (Eds.).(2010). poverty and disability. Leonard Cheshire Disability.

Braithwaite, J., \& Mont, D. (2007). Disability and poverty: $A$ survey of world bank poverty assessments and implications.

Bruijn, P., Regier, B., Cornielje, H., Wolting, R., van Veen, S. \& Maharaj, N. (2012). Count me in: Include people with disabilities in development projects - A practical guide for organizations in North and South. http://www.light fortheworld.nl/docs/defaultsource/capacity-building/count-mein---include-people-with-disabilitiesin-developmentprojects. pdf?sfvrsn $=18$.

Cappo, D. M. (2002). Quoted in VicHealth Research summary 2 - social inclusion as

determinant of mental health \& well being (January 2005) http://www.h ealth.vic.gov.au/agedcare/maintaini ng/countusin/inclusion.htm.

Carter, B. (2015). Benefits to society of an inclusive society approach (GSDRC Helpdesk Research Report 1232). GSDRC, University of Birmingham.

CBM. (2012). Inclusion made easy. http:// www.cbm.org/article/ downloads/788 51/CBM_Inclusion_Made_Easy__Part_A.pdf.

Chartered Institute of Personnel and Devel opment. (2019). Building inclusive wo rkplaces assessing

the evidence Research report. cipd. www.cipd.co.uk/knowledge/work/tren ds/uk-working-lives.

Clarke, J. (2016). Key statistics on people with disabilities in employment. House of Commons Library briefing paper 7540 .

Coe, S. (2012). More practical lessons from five projects on Disability inclusive de velopment. Development in Practice, 22(3), 400-408.

http://dx.doi.org/10.1080/09614524. 2012.664629.

Coe, S., \& Wapling, L. (2010). Practical les sons from four projects on Disability-I nclusive development programming. Development in Practice, 20 (7), 879886. http://dx.doi.org/10.1080/0961 4524.2010.508109.

Corporation for National and Community Se rvice. (2004). Creating an inclusive e nvironment: A handbook for the inclu sion of people with disabilities in natio nal and community service programm es. UCP Access AmeriCorps disability inclusion training and technical assistance project.

Department for International Development (DFID). (2002). Disability, poverty, and development. http://www.dfid.gov.uk/pubs/files/dis ability.pdf

Department for International Development (DfID). (2000). Disability, Poverty, an $d$ Development.

http://hpod.org/pdf/Disabilitypoverty-and-development.pdf 
DESA.(2011). Best practices for including persons with disabilities in all aspects of development efforts. UN. http://www.un.org/disabi lities/documents/best practices publi cation 2011.pdf.

Equality and Human Rights Commission [EHRC] (2013), Modern apprenticeships: Equality and the economy - spreading the benefits. EHRC.

Equality and Human Rights Commission [EHRC] (2014). Cumulative impact assessment: A research report by Landman Economics and the National Institute of Economic and Social Research (NIESR). EHRC Research report 94.

Ferrie, D. (2008). Social inclusion and place-based disadvantage,' proceedings from social inclusion and placebased disadvant age workshop. Brotherhood of St La urence. http://www.bsl.org.au/pdfs /Ferrie_workshop_paper_13Jun08.p df

Groce, N. \& Kett, M. (2014). Youth with disabilities (Working Paper Series: No. 23). London: Leonard Cheshire Disability and Inclu sive Development Centre. https://ww w.ucl.ac.uk/lcccr/centrepublications/ workingpapers/WP23 Youth with Dis abilities.pdf

Heymann, J., Stein, M. A. \& Moreno, G. (Eds.).(2014). Disability and equality at work. Oxford University Press.

Hodkinson, A. (2011). Inclusion: A defining definition? Power and Education, 3 (2), 179-185. Http://dx.doi.org/10.2304/power.2 011.3.2.179.

International Disability and Development C onsortium (IDDC). (2012). Making In clusion a reality in development orga nisations: A manual for advisors in di sability mainstreaming. http://www.i ddcconsortium.net/sites/default/files/ resources-tools/files/121200 iddc tot $\mathrm{m}$ digi revised.pdf.

Joseph Rowntree Foundation [JRF] (2016). Special educational needs and their links to poverty. JRF.

Mitra, S. (2013). A data revolution for Disa bility inclusive development. Lancet $G$ lobal Health, 1 (4), e178 - e179. http://dx.doi.org/10.1016/S2214109X(13)70016-0.

Morgon, B. L., \& Pollack, S. (2014). The ec onomic costs of exclusion and gains $O$ $f$ inclusion of people with disabilities: Evidence from low and middle-income countries. CBM, International Centre for Evidence in Disability, London Sch ool of Hygiene \& Tropical Medicine. ht tp://disabilitycentre.Ishtm.ac.uk/files/ 2014/07/Costs-of-Exclusion-andGains-of-Inclusion-Report.pdf.

Nordic Consulting Group (NCG). (2012). Mainstreaming disability in the new development paradigm: Evaluation of Norwegian support to promote the rights of persons with disabilities. NORAD. http://www.norad.no/en/tool spublications/publications/2012/main streaming-disability-in-the-newdevelopment-paradigm-evaluation-ofnorwegian-support-to-promote-therights-of-persons-with-disabilities/.

Rohwerder, B. (2015). Disability inclusion: Topic guide. GSDRC, University of Birmingham

Smith, F., Jolley, E., \& Schmidt, E. (2012). Disability and disasters: The importance of an inclusive approach to vulnerability and social $c$ apital. The world we want. https://w ww.worldwewant2015.org/node/2870 97.

United Nations Department of Economic and Social Affairs (UNDESA). (2011). Disability and the millennium development goals: A Review of the MDG process and strategies for inclusion of disability issues in millennium development goal efforts

United Nations. (2013). A life of dignity for all: Accelerating progress towards the millennium development goals and advancing the United Nations development agenda beyond 2015. Report of the Secretary-

General. A/68/202, UN. http://www.u n.org/millenniumgoals/pdf/A\%20Life \%20of\%20 Dignity\%20for\%20All.pdf.

United Nations Department of Economic and Social Affairs (UNDESA).(2011). Disability and the millennium development goals. A review of the MDG process and 
strategies for inclusion of disability issues in millennium develo pment goal efforts. http://www.un.or $\mathrm{g} /$ disabilities/documents/review of di sability and the mdgs.pdf.

United Nations Development Programme ( UNDP). (2010). Human development Report. http://hdr.undp.org/sites/def ault/files/reports/270/hdr 2010 en C omplete reprint.pdf.

Walton, O. (2012). Economic benefits of dis abilityinclusive development (GSDRC Helpdesk Research Report 831). GSD RC. http://www.gsdrc.org/docs/open/HD Q831.pdf.

Wapling, L., \&Downie, B. (2012). Beyond charity: A donor's guide to inclusion Disability funding in the era of the UN Convention on the Rights of Persons with Disabilities. Disability Rights Fund. http://www. disabilityrig htsfund.org/files/beyond charity. a donors guide to inclusion.pdf.

Wissenbach, L. (2014). Pathways to inclusive development: How to make Disability inclusive practice measurable? (Discussion Pap ers on Social Protection). GIZ. http:/ /www.giz.de/expertise/downloads/giz 2014-en-pathways-to-inclusivedevelopment.pdf.

WRC. (2015). 'I see that it is possible': Building capacity for disability inclusion in gender-based violence programming in humanitarian settings. Women's Refugee Commission.

https://womensrefugeecommission.or $\mathrm{g} /$ resources/document/945-buildingcapacity-for-disability-inclusion-ingender-based-violence-gbvprogramming-in-humanitariansettings-overview.

World Bank (2013). Inclusion matters: The Foundation for Shared Prosperity. Washington, DC: World Bank. ISBN 978-1-4648-0010-8.

World Health Organisation \& World Bank, World Report on Disability, Summary Report. (2011) Geneva: WHO. http://whqlibdoc.who.int/hq/2011/W HO NMH VIP 11.01 eng.pdf. 